Jurnal Keperawatan Silampari

Volume 3, Nomor 2, Juni 2020

e-ISSN: 2581-1975

p-ISSN: 2597-7482

DOI: https://doi.org/10.31539/jks.v3i2.1188

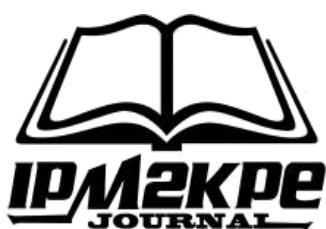

\title{
PEMBERDAYAAN IBU UNTUK PERBAIKAN POLA KONSUMSI IKAN TERHADAP PENINGKATAN ASUPAN PROTEIN, KALSIUM, ZINK DAN Z-SCORE TINGGI BADAN MENURUT UMUR PADA ANAK STUNTING
}

\author{
Oslida Martony ${ }^{1}$, Dini Lestrina ${ }^{2}, \mathrm{Zul}_{\mathrm{Amri}}{ }^{3}$ \\ Politeknik Kesehatan Kementerian Kesehatan Medan ${ }^{1,2}$ \\ Politeknik Kesehatan Kementerian Kesehatan Padang ${ }^{3}$ \\ oslida64@gmail.com ${ }^{1}$
}

\begin{abstract}
ABSTRAK
Tujuan penelitian ini adalah untuk megetahui pengaruh pemberdayaan ibu untuk perbaikan pola konsumsi ikan terhadap peningkatan asupan protein, kalsium, zink dan Z-score tinggi badan menurut umur pada anak stunting. Jenis penelitian ini adalah Quasi Eksperimental dengan rancangan pre dan post test desain control group. Hasil penelitian menunjukkan peningkatan pengetahuan ibu, peningkatan asupan protein, kalsium dan seng serta peningkatan skor TB / Setelah intervensi pada kelompok kasus, dibandingkan dengan kelompok kontrol, tidak ada perbedaan dalam protein, asupan kalsium dan Zscore TB / U, peningkatan pemberdayaan ibu meningkatkan asupan anak stunting dan sama dengan asupan anak tidak stunting. Simpulan, Ada perbedaan yang bermakna nilai rata-rata asupan protein, kalsium, zink dan Z-score sebelum dan sesudah pemberian intervensi pemberdayaan ibu untuk perbaikan pola konsumsi ikan pada anak usia 13-36 bulan.
\end{abstract}

Kata Kunci: Asupan, Kalsium, Pemberdayaan Ibu, Protein, Seng, Stunting, Z-Score $\mathrm{TB} / \mathrm{U}$

\begin{abstract}
This study aimed to determine the effect of maternal empowerment on improving fish consumption patterns to increase protein intake, calcium, zinc, and Z-score height by age when stunting children. The type of this research is Quasi-Experimental with pre and post-test control group design. The results showed an increase in maternal knowledge, increased intake of protein, calcium, and zinc as well as an increase in TB scores / After the intervention in the case group, compared to the control group, there were no differences in protein, calcium intake and $Z$-score $T B / U$, an increase in maternal empowerment increased intake of children stunting and the same as intake of children not stunting. Conclusion There is a significant difference in the average value of protein intake, calcium, zinc, and Z-score before and after providing maternal empowerment interventions to improve fish consumption patterns in children aged 1336 months.
\end{abstract}

Keywords: Intake, Calcium, Maternal Empowerment, Protein, Zinc, Stunting, Z-Score $T B / U$ 


\section{PENDAHULUAN}

Nutrisi yang diberikan pada masa anak-anak dianggap sebagai fase yang sangat penting karena akan menentukan kualitas kesehatan anak dimasa mendatang (Padila et al., 2018; Panzilion et al., 2020). Kesehatan, kesejahteraan, pembelajaran, dan perilaku dimasa yang akan datang serta masa depan masyarakat tergantung pada anak-anak yang mampu mencapai pertumbuhan dan perkembangan yang optimal (Padila et al., 2019; WHO, 2017).

Stunting merupakan kondisi gagal tumbuh pada anak balita akibat kekurangan gizi kronis sehingga anak lebih pendek untuk usianya. Kekurangan gizi terjadi sejak bayi dalam kandungan dan pada masa awal kehidupan setelah lahir, tetapi baru tampak setelah anak berusia 2 tahun. Stunting disebabkan oleh faktor multidimensi sehingga penanganannya perlu dilakukan multisektor diantaranya praktik pengasuhan yang tidak baik, terbatasnya layanan kesehatan termasuk ante natal care, post natal dan pembelajaran dini yang berkualitas, kemudian kurangnya akses ke makanan bergizi dan kurangya akses ke air bersih dan sanitasi (Kementerian Kesehatan, 2019).

Dampak kesehatan dari stunting ini adalah gagal tumbuh (berat lahir rendah, kecil, pendek, kurus), hambatan perkembangan kognitif dan motorik, gangguan metabolik pada saat dewasa yang berisiko terhadap penyakit tidak menular (diabetes, obesitas, stroke dan penyakit jantung) (Kementerian Kesehatan, 2019).

Indonesia termasuk dalam 17 negara diantara 117 negara yang mempunyai prevalensi tinggi stunting, wasting dan overweight pada balita yaitu masing-masing $37,2 \% ; 12,1 \% ; 11,9 \%$. Sesuai batasan oleh WHO dikatakan masalah kesehatan masyarakat apabila stunting pada balita $\geq 20 \%$; wasting pada balita $\geq 5 \%$ dan overweight $\geq 7 \%$. Salah satu variabel pada model IPKM adalah prevalensi balita sangat pendek dan pendek. Prevalensi sangat pendek dan pendek sejak Riskesdas 2007, 2010, 2013 dan 2018 menunjukkan perubahan yang sangat kecil baik untuk level nasional maupun level propinsi. Prevalensi sangat pendek dan pendek untuk Indonesia 36,8\%; $35,6 \% ; 37,2 \% ; 30,8 \%$, sedangkan prevalensi tingkat provinsi Sumatera Utara dan Sumatera Barat berdasarkan Riskesdas 2018 masih di atas angka 30\%. Hal ini menunjukkan angka prevalensi yang masih cukup tinggi, dan masalah kesehatan di masyarakat dianggap berat bila prevalensi pendek sebesar 30-39\% dan serius bila prevalensi pendek $\geq 40 \%$ (Gultom, Nainggolan, 2019; Widianto, 2018).

Hasil penelitian Rahmawati pada tahun 2017 menunjukkan pada kelompok stunting rata-rata persen kecukupan protein sebesar 76,62\%, zinc 35,84\%, kalsium $30,96 \%$, vitamin D 14,44\%, sedangkan kelompok non-stunting kecukupan protein sebesar $88,57 \%$, zinc 40,26\%, kalsium 30,96\%, vitamin D 19,79\%. Terdapat perbedaan kecukupan protein, zinc, kalsium pada remaja putri stunting dan non-stunting, sedangkan kecukupan vitamin D tidak terdapat perbedaan remaja putri stunting dan non-stunting (Rahmawati, Hidayati, 2017).

Selama pertumbuhan, tuntutan terhadap mineralisasi tulang sangat tinggi, rendahnya asupan kalsium dapat mengakibatkan rendahnya mineralisasi matriks deposit tulang baru dan disfungsi osteoblast. Defisiensi kalsium akan mempengaruhi pertumbuhan linier jika kandungan kalsium dalam tulang kurang dari 50\% kandungan normal. Rendahnya TB/U pada anak dikarenakan rendahnya asupan protein beserta rendahnya konsumsi yodium dan zink. Ditemukan asupan mikronutrien yang signifikan lebih rendah pada anak stunting dibandingkan dengan anak tidak stunting (Sari et al., 2016). Kegagalan pertumbuhan dapat disebabkan oleh tidak memadainya asupan dari 
satu atau lebih zat gizi seperti asupan mikronutrien yaitu kalsium dan zink (Kartini et al., 2016).

Ikan memiliki peran penting sebagai sumber energi, protein dan variasi nutrien esensial yang menyumbang sekitar $20 \%$ dari total protein hewani. Protein dari ikan merupakan komponen nutrisi yang penting bagi negara yang memiliki jumlah penduduk tinggi di mana kecukupan proteinnya berada pada level rendah/kurang. Mengkonsumsi ikan sangat penting selama masa kehamilan dan dua tahun pertama kehidupan serta dapat membantu menurunkan resiko kematian akibat serangan jantung. Perhatian yang tak kalah penting berfokus pada produk perikanan sebagai sumber mikronutrien seperti vitamin dan mineral. Hal ini terutama berlaku untuk spesies ikan berukuran kecil yang dikonsumsi seluruh mulai dari bagian kepala hingga tulang, yang dapat menjadi sumber mineral penting yang sangat baik seperti yodium, selenium, seng, besi, kalsium, fosfor dan kalium, dan juga vitamin seperti vitamin A dan vitamin D, dan beberapa vitamin dari kelompok B (Rachim, Pratiwi, 2017).

Peningkatan konsumsi ikan dapat menjadi salah satu cara untuk penanggulangan stunting, hanya saja konsumsi ikan pada balita masih rendah karena ikan memang masih menjadi sumber protein yang kedua setelah daging. Konsumsi ikan menjadi rendah karena ditingkat pengolahan ikan lebih sering hanya digoreng, untuk meningkatkan konsumsi ikan mungkin membutuhkan tambahan keterampilan untuk mengolah dan menyajikan ikan yang sesuai untuk konsumen muda. Kurangnya pengetahuan mengenai cara memasak ikan menjadi salah satu hambatan dalam mengkonsumsi ikan.

Desa Paluh Sibaji Kecamatan Pantai Labu Kabupaten Deli Serdang dan Desa ApiApi Pasar Baru Kecamatan Bayang di Kabupaten Pesisir Selatan merupakan wilayah yang berada di pesisir pantai, hasil survey data sementara dari hasil pengukuran, di Desa Paluh Sibaji dari 119 balita ditemukan 52 balita yang mengalami stunting, begitu juga di Desa Api-Api, dari 94 balita yang diukur ditemukan 45 balita yang stunting. Penelitian anak stunting sudah banyak dilakukan yang memfokuskan pada salah satu variabel saja. Namun penelitian ini menghubungkan beberapa variabel dan selama ini belum ada penelitian tentang pemberdayaan ibu untuk perbaikan pola konsumsi ikan terhadap peningkatan asupan protein, kalsium, zink dan Z-Score tinggi badan menurut umur pada anak stunting di kabupaten pesisir selatan khususnya Desa Paluh Sibaji.

\section{METODE PENELITIAN}

\section{Jenis dan Rancangan Penelitian}

Jenis penelitian ini adalah quasi eksperimental dengan rancangan pre dan post test desain control group.

\section{Lokasi dan Waktu Penelitian}

Penelitian ini dilakukan pada dua desa yang berbeda namun memiliki kesamaan lokasi yaitu berada di daerah pinggir pantai yaitu Desa Paluh Sibaji Kecamatan Pantai Labu Kabupaten Deli Serdang dan Desa Api-Api Kecamatan Bayang Kabupaten Pesisir Selatan. Penelitian dilaksanakan mulai Januari sampai dengan Oktober 2019.

\section{Populasi dan Sampel}

Populasi pada penelitian ini yaitu semua anak usia 13-36 bulan yang mengalami stunting di Desa Paluh Sibaji Kecamatan Pantai Labu Kabupaten Deli Serdang dan Desa Api-Api Kecamatan Bayang Kabupaten Pesisir Selatan. 
Sampel adalah anak usia 13-36 bulan yang mengalami stunting di Desa Paluh Sibaji Kecamatan Pantai Labu Kabupaten Deli Serdang dan Desa Api-Api Kecamatan Bayang Kabupaten Pesisir Selatan. Sampel ditentukan dengan melakukan skrining sesuai dengan kriteria anak usia 13-36 bulan tidak mengalami penyakit infeksi kronis, anak usia 13-36 bulan tidak alergi terhadap ikan dan telur, ibu dari sampel penelitian bersedia untuk bekerjasama sampai selesai kegiatan pemberdayaan konsumsi ikan pada anaknya.

\section{Langkah-Langkah Penelitian \\ Pra Intervensi}

Pengisian persetujuan sebelum penelitian (PSP), menjelaskan kepada ibu tentang kegiatan penelitian yang akan dilakukan dan meminta komitmen ibu untuk mau mengikuti kegiatan tersebut sampai proses pengumpulan data berakhir. Mengukur tinggi badan anak, ke,udian melakukan food recall 2x24 jam, untuk mengetahui konsumsi makanan anak sehari-hari. Menghitung z-score TB/U anak dan menghitung jumlah asupan protein, kalsium dan zink dari konsumsi makanan harian anak.

\section{Intervensi}

Penyuluhan kepada ibu yang memiliki anak stunting tentang manfaat dari ikan laut, dilakukan satu kali di wilayah penelitian. Edukasi kepada ibu tentang kebutuhan konsumsi ikan pada anak stunting, dilakukan 2 kali sebelum pemberian contoh makanan yang berbahan ikan Lemuru. Dalam melakukan penyuluhan dan edukasi maka peneliti menggunakan booklet sebagai alat bantu, sehingga ibu memiliki panduan dalam jumlah kebutuhan ikan pada anaknya. Pelatihan pengolahan ikan lemuru dalam bentuk nugget ikan, bola ikan, dan dadar gulung isi ikan dilakukan 1 kali. Kegiatan penyuluhan, edukasi dan demo pengolahan makanan berbahan ikan seluruhnya dilakukan di kantor Kepala Desa Paluh Sibaji dan Kantor Wali Nagari Desa Api-Api.

Pemberian makanan selingan berbahan ikan lemuru setiap hari selama 21 hari pada anak yang stunting. Pemberian Nugget ikan lemuru ini dilakukan dengan mengantar langsung setiap hari pada jam 10.00 WIB ke rumah, memastikan makanan tersebut dimakan oleh sampel. Monitoring dan evaluasi dilakukan setiap 2 minggu sekali dengan cara wawancara terhadap makanan yang dikonsumsi anak. Pengukuran tinggi badan setiap sebulan sekali, kegiatan awal dilakukan di kantor Kepala Desa Paluh Sibaji dan Kantor Wali Nagari Api-Api, pengukuran selanjutnya, untuk sampel dari Desa Paluh Sibaji dilakukan kembali di Kantor Kepala Desa Paluh Sibaji, sedangkan untuk sampel dari Desa Api-Api, pengukuran dilakukan langsung ketika mengunjungi rumah sampel. Food recall 1x24 jam, dilakukan ketika melakukan evaluasi makan anak.

\section{Analisis Univariat}

Analisis univariat dilakukan untuk menggambarkan masing-masing variabel yang disajikan dalam tabel distribusi frekuensi dan tabel nilai rata-rata.

\section{Analisis Bivariat}

Analisis bivariat untuk melihat perbedaan nilai rata-rata asupan protein, kalsium, zink dan Z-score TB/U antara kelompok kasus dan kontrol, sebelum dan sesudah pemberian intervensi. Langkah awal yang dilakukan adalah melakukan uji kenormalan data antara kelompok kontrol dan kelompok perlakuan dengan menggunakan uji 
Crosstabs dengan nilai $\mathrm{p}>\alpha$ sehingga disimpulkan bahwa tidak ada perbedaan antara kelompok kontrol dan kelompok kasus.

Untuk data hasil penelitian, sebelum dilakukan uji statistik dengan menggunakan uji beda yaitu paired t test dan Independent samples test, dilakukan uji kenormalan data menggunakan One-Sample Kolmogorov-Smirnov Test.

\section{HASIL PENELITIAN \\ Karakteristik Anak Umur 13-36 Bulan}

Tabel. 1

Distribusi Anak Berdasarkan

Umur dan Jenis Kelamin

\begin{tabular}{lcccc}
\hline & \multicolumn{2}{c}{ Kelompok Pemberdayaan } & \multicolumn{2}{c}{ Kelompok Non Pemberdayaan } \\
& $\mathrm{n}$ & $\%$ & $\mathrm{n}$ & $\%$ \\
\hline Jenis Kelamin: & & & 26 & 55,3 \\
$-\quad$ Laki-laki & 30 & 50,0 & 21 & 44,7 \\
- Perempuan & 30 & 50,0 & & \\
\hline Umur : & & & 25 & 53,2 \\
$-\quad 13-24$ bulan & 28 & 46,7 & 26 & 46,8 \\
\hline - 25-36 bulan & 32 & 53,3 & 47 & 100 \\
\hline Jumlah & 60 & 100 & & \\
\hline
\end{tabular}

Berdasarkan tabel 1 diketahui bahwa jenis kelamin pada kelompok pemberdayaan di kedua desa memiliki kesamaan dimana 50\% laki-laki dan 50\% perempuan. Sedangkan pada kelompok non pemberdayaan, sebagian besar anak laki-laki $(55,3, \%)$. Pada karakteristik umur kelompok pemberdayaan sebagian besar pada kelompok umur 25-36 bulan sebesar 53,3\%, namun pada kelompok non pemberdayaan, dari kedua desa tersebut sebagian besar pada umur $13-24$ bulan $(53,2 \%)$.

\section{Karakteristik Ibu}

Tabel. 2

Distribusi Ibu Berdasarkan Umur, Pendidikan dan Pekerjaan

\begin{tabular}{lcccc}
\hline \multicolumn{1}{c}{ Kategori } & \multicolumn{2}{c}{ Kelompok Pemberdayaan } & \multicolumn{2}{c}{ Kelompok Non Pemberdayaan } \\
& $\mathrm{N}$ & $\%$ & $\mathrm{~N}$ & $\%$ \\
\hline Umur : & & & & \\
- 20-30 tahun & 26 & 43,3 & 28 & 59,6 \\
- $\quad 31-40$ tahun & 32 & 53,3 & 17 & 36,2 \\
- > 40 tahun & 2 & 3,3 & 2 & 4,3 \\
\hline Pendidikan : & & & 2 & 4,3 \\
- Tidak Tamat & 1 & 1,7 & & 21,3 \\
SD & & & 10 & 38,3 \\
- SD & 15 & 25,0 & 18 & 31,9 \\
- SMP & 17 & 28,3 & 15 & 4,3 \\
- SMA/SMK & 23 & 38,3 & 2 & 93,6 \\
- Ak/PT & 4 & 6,7 & & 6,4 \\
\hline Pekerjaan : & & & 44 & 100 \\
- IRT & 58 & 96,7 & 3 & \\
- Pegawai & 2 & 3,3 & 47 & \\
\hline Jumlah & 60 & 100 & & \\
\hline
\end{tabular}


Berdasarkan tabel 2 dapat diketahui bahwa distribusi umur ibu dari kelompok pemberdayaan dan non pemberdayaan memiliki perbedaan, tetapi secara keseluruhan termasuk dalam kelompok umur wanita usia subur (15-49 tahun), pada kelompok pemberdayaan sebagian besar pada kelompok umur 31-40 tahun sebesar 53,3\% dan non pemberdayaan sebagian besar di usia 20-30 tahun sebesar 59,6\%, yang berarti pada umur yang produktif.

Jika dilihat dari segi pendidikan, rata-rata ibu dari kelompok pemberdayaan sebagian besar dengan tingkat pendidikan SMA, diikuti dengan tingkat pendidikan SD dan SMP, sebagian kecil dengan pendidikan perguruan tinggi. Di sedangkan pada kelompok non pemberdayaan, sebagian besar dengan pendidikan SMP, diikuti SMA dan SD, sebagian kecil perguruan tinggi.

\section{Karakteristik Ayah}

Tabel. 3

Distribusi Ayah Berdasarkan Umur, Pendidikan dan Pekerjaan

\begin{tabular}{lcccc}
\hline \multicolumn{1}{c}{ Kategori } & Kelompok Pemberdayaan & \multicolumn{2}{c}{ Kelompok Non Pemberdayaan } \\
& $\mathrm{N}$ & $\%$ & $\mathrm{n}$ & $\%$ \\
\hline Umur : & & & 20 & 42,6 \\
- 20-30 tahun & 16 & 26,7 & 21 & 44,7 \\
- 31-40 tahun & 38 & 63,3 & 6 & 12,8 \\
- > 40 tahun & 6 & 10,0 & 1 & 2,1 \\
\hline Pendidikan : & & & 15 & 31,9 \\
- Tidak Tamat SD & 2 & 3,3 & 17 & 36,2 \\
- SD & 13 & 21,7 & 13 & 27,7 \\
- SMP & 21 & 35,0 & 1 & 2,1 \\
- SMA/SMK & 22 & 36,7 & & \\
- Ak/PT & 2 & 3,3 & 27 & 57,4 \\
\hline Pekerjaan : & & & 2 & 4,2 \\
- Nelayan & 31 & 51,7 & 6 & 12,8 \\
- Pedagang & 4 & 6,7 & 6 & 12,8 \\
- Wiraswasta & 13 & 21,7 & 6 & 12,8 \\
- Buruh & 4 & 6,7 & 47 & 100 \\
- Petani & 8 & 13,3 & 100 & \\
\hline Jumlah & 60 & & & \\
\hline
\end{tabular}

Berdasarkan tabel 3 menggambarkan umur ayah yang sebagian besar pada umur 20-40 tahun, sesuai dengan kelompok umur ibu. Pada kelompok pemberdayaan sebagian besar ayah dari sampel berada pada rentang umur 31-40 tahun sebesar 63,3\%, begitu juga pada kelompok non pemberdayaan sebesar 44,7\%. Kelompok umur ini juga termasuk ke dalam umur yang produktif.

Pada tingkat pendidikan ayah juga hampir sama dengan tingkat pendidikan ibu, dimana untuk kelompok pemberdayaan sebagian besar dengan pendidikan SMA, diikuti pendidikan SMP dan SD, sedangkan pada kelompok non pemberdayaan sebagian besar pendidikan SMP, diikuti SD dan SMA. Gambaran ini menunjukkan masih rendahnya pendidikan pada kedua kelompok tersebut.

Untuk pekerjaan dari ayah, sebagian besar pada kedua desa dengan pekerjaan sebagai nelayan, hal ini sesuai dengan letak demografis daerah yang memang berada di daerah pesisir pantai. 


\section{Gambaran Pengetahuan Ibu}

Tabel. 4

Nilai Rata-Rata Skor Pengetahuan

Ibu Kelompok Pemberdayaan

\begin{tabular}{lcccc}
\hline \multicolumn{1}{c}{ Pengetahuan Ibu } & \multicolumn{2}{c}{ Sebelum } & \multicolumn{2}{c}{ Sesudah } \\
& $\mathrm{N}$ & $\%$ & $\mathrm{n}$ & $\%$ \\
\hline Baik & 5 & 8,3 & 47 & 78,3 \\
Kurang & 55 & 91,7 & 13 & 21,7 \\
\hline Jumlah & 60 & 100 & 47 & 100 \\
\hline
\end{tabular}

Berdasarkan tabel 4 dapat dilihat bahwa gambaran pengetahuan ibu dari anak umur 13-36 bulan yang mengalami stunting, setelah dan sebelum diberikan intervensi memiliki perbedaan. Sebelum dilakukan intervensi pemberdayaan terlihat bahwa pengetahuan ibu tentang stunting dan tentang manfaat ikan dan jumlah porsi yang diberikan kepada anak umur 13-36 bulan dalam kategori kurang sebesar 91,7\%. Setelah dilakukan intervensi kepada ibu dengan melakukan penyuluhan dan edukasi menggunakan alat bantu booklet yang disusun secara sederhana, dan demo masak makanan berbahan ikan, maka terjadi perubahan tingkat pengetahuan dari sebagian besar kurang menjadi baik 78,3\%.

\section{Analisis Bivariat Asupan Protein, Kalsium dan Zink Sebelum dan Sesudah Intervensi Asupan Protein}

Tabel. 5

Nilai Rata-Rata Asupan Protein

\begin{tabular}{lcccc}
\hline \begin{tabular}{c} 
Asupan Protein \\
\multicolumn{1}{c}{$(\mathrm{gr})$}
\end{tabular} & \multicolumn{2}{c}{ Pemberdayaan } & \multicolumn{2}{c}{ Non pemberdayaan } \\
Rata-Rata & 20,99 & Sebelum & Sebelum & Sesudah \\
SD & 3,18 & 3,73 & 26,25 & 28,83 \\
Minimum & 13,50 & 18,30 & 4,11 & 4,64 \\
Maksimum & 26,70 & 36,20 & 33,70 & 20,44 \\
p value & & & \multicolumn{2}{c}{0,0001} \\
Mean Different. & \multicolumn{2}{c}{0,0001} & & \multicolumn{2}{c}{2,58} \\
N & 6,54 & & \multicolumn{2}{c}{47} \\
\hline
\end{tabular}

Berdasarkan tabel 5 dapat diketahui bahwa rata-rata asupan protein pada kelompok pemberdayaan sebelum dilakukan intervensi sebesar 20,99 gr/hari Sedangkan pada kelompok non pemberdayaan, asupan protein lebih tinggi yaitu sebesar 26,25 gr/hari. Setelah dilakukan intervensi pada kelompok pemberdayaan, asupan protein telah meningkat dengan nilai rata-rata $27,54 \mathrm{gr} / \mathrm{hari}$, jumlah ini tidak jauh berbeda dengan kelompok non pemberdayaan dinilai rata-rata asupan protein sebesar $28,83 \mathrm{gr} / \mathrm{hari}$. Hasil uji statistik diperoleh nilai p $(0,0001)<\alpha(0,05)$. Ada perbedaan nilai rata-rata asupan protein sebelum dan sesudah intervensi pada kedua kelompok. 


\section{Asupan Kalsium (Ca)}

Tabel. 6

Nilai Rata-Rata Asupan Kalsium (Ca)

\begin{tabular}{|c|c|c|c|c|}
\hline \multirow{2}{*}{$\begin{array}{l}\text { Asupan Kalsium } \\
(\mathrm{mg})\end{array}$} & \multicolumn{2}{|c|}{ Pemberdayaan } & \multicolumn{2}{|c|}{ Non pemberdayaan } \\
\hline & Sebelum & Sesudah & Sebelum & Sesudah \\
\hline Rata-Rata & 197,30 & 293,11 & 245,96 & 291,93 \\
\hline SD & 78,48 & 99,11 & 79,03 & 84,50 \\
\hline Minimum & 92,30 & 148,10 & 134,10 & 180,10 \\
\hline Maksimum & 446,70 & 667,80 & 506,00 & 594,40 \\
\hline $\mathrm{p}$ value & \multicolumn{2}{|c|}{0,0001} & \multicolumn{2}{|c|}{0,001} \\
\hline Mean Different. & \multicolumn{2}{|c|}{95,80} & \multicolumn{2}{|c|}{45,96} \\
\hline $\mathrm{N}$ & \multicolumn{2}{|c|}{60} & \multicolumn{2}{|c|}{47} \\
\hline
\end{tabular}

Berdasarkan tabel 6 diketahui bahwa rata-rata asupan kalsium pada kelompok pemberdayaan sebelum dilakukan intervensi sebesar 197,30 mg/hr. Asupan kalsium ini hanya memenuhi 30,3\% dari AKG, dimana kebutuhan anak usia 13-36 bulan sebesar $650 \mathrm{mg} / \mathrm{hari}$. Setelah dilakukan intervensi tampak terjadi penambahan asupan kalsium dengan nilai rata-rata penambahan sebesar $95,8 \mathrm{mg} / \mathrm{hari}$ pada kelompok pemberdayaan, sehingga nilai rata-rata asupan menjadi sebesar $293,11 \mathrm{mg} / \mathrm{hari}$.

Hasil uji statistik pada kelompok pemberdayaan memberikan hasil nilai $p$ $(0,0001)<\alpha(0,05)$ sehingga dapat disimpulkan ada perbedaan nilai rata-rata asupan kalsium sebelum dan sesudah pemberian intervensi.

\section{Asupan Zink (Zn)}

Tabel. 7

Nilai Rata-Rata Asupan Zink (Zn)

\begin{tabular}{|c|c|c|c|c|}
\hline \multirow{2}{*}{$\begin{array}{l}\text { Asupan Kalsium } \\
(\mathrm{mg})\end{array}$} & \multicolumn{2}{|c|}{ Pemberdayaan } & \multicolumn{2}{|c|}{ Non pemberdayaan } \\
\hline & Sebelum & Sesudah & Sebelum & Sesudah \\
\hline Rata-Rata & 3,69 & 5,16 & 3,57 & 3,96 \\
\hline SD & 1,36 & 1,26 & 1,15 & 1,02 \\
\hline Minimum & 1,20 & 3,10 & 1,10 & 2,32 \\
\hline Maksimum & 6,80 & 8,40 & 5,80 & 6,20 \\
\hline $\mathrm{p}$ value & \multicolumn{2}{|c|}{0,0001} & \multicolumn{2}{|c|}{0,049} \\
\hline Mean Different. & \multicolumn{2}{|c|}{1,47} & \multicolumn{2}{|c|}{0,38} \\
\hline $\mathrm{N}$ & \multicolumn{2}{|c|}{60} & \multicolumn{2}{|c|}{47} \\
\hline
\end{tabular}

Berdasarkan tabel 7 dapat diketahui bahwa nilai rata-rata asupan zink sebelum intervensi pada kelompok pemberdayaan sebesar 3,69 mg/hari. Asupan ini sudah memenuhi $>80 \%$ dari AKG pada anak usia 13-36 bulan. Setelah dilakukan intervensi maka diketahui asupan zink meningkat menjadi $5,16 \mathrm{mg} / \mathrm{hr}$, asupan zink ini memenuhi AKG sebesar $>100 \%$. Hasil uji statistik pada kelompok pemberdayaan memberikan hasil nilai $\mathrm{p}(0,0001)<\alpha(0,05)$ sehingga dapat disimpulkan ada perbedaan nilai rata-rata asupan zink sebelum dan sesudah pemberian intervensi.

Sedangkan pada kelompok non pemberdayaan diketahui bahwa nilai rata-rata asupan zink pada awal pengukuran sebesar 3,57 mg/hr dan pengukuran akhir sebesar $3,96 \mathrm{mg} / \mathrm{hr}$. 


\section{Analisis Bivariat Z-Score TB/U Sebelum dan Sesudah Intervensi}

Tabel. 8

Nilai Rata-Rata Z-Score TB/U

\begin{tabular}{lcccc}
\hline \multicolumn{1}{c}{ Z-Score TB/U } & \multicolumn{2}{c}{ Pemberdayaan } & \multicolumn{2}{c}{ Non pemberdayaan } \\
& Sebelum & Sesudah & Sebelum & Sesudah \\
\hline Rata-Rata & $-2,46$ & $-2,25$ & $-0,41$ & $-0,29$ \\
SD & 0,53 & 0,56 & 1,06 & 1,02 \\
Minimum & $-4,53$ & $-4,19$ & $-1,92$ & $-1,62$ \\
Maksimum & $-2,00$ & $-1,60$ & 2,76 & 2,65 \\
p value & \multicolumn{2}{c}{0,0001} & \multicolumn{2}{c}{0,0001} \\
Mean Different. & \multicolumn{2}{c}{$-0,21$} & \multicolumn{2}{c}{$-0,11$} \\
N & \multicolumn{2}{c}{60} & & \\
\hline
\end{tabular}

Berdasarkan tabel 8 dapat dilihat bahwa pada kelompok pemberdayaan memiliki nilai rata-rata $\mathrm{Z}$-score $\mathrm{TB} / \mathrm{U}$ sebelum intervensi sebesar -2,46. Setelah dilakukan intervensi nilai Z-score $\mathrm{TB} / \mathrm{U}$ mengalami penurunan nilai minus menjadi $-2,25$. Hasil uji statistik menunjukkan nilai $\mathrm{p}(0,0001)$ sehingga dapat disimpulkan bahwa ada perbedaan yang bermakna nilai rata-rata $\mathrm{z}$-score $\mathrm{TB} / \mathrm{U}$ sebelum dan sesudah intervensi.

Sedangkan pada kelompok non pemberdayaan adalah kelompok yang bukan stunting, nilai rata-rata $\mathrm{z}$-score pada awal pengukuran sebesar -0,41 dan pengukuran akhir sebesar -0,29 artinya pada kelompok non pemberdayaan juga ada perubahan nilai rata-rata z-score yang bermakna.

Tabel. 9

Status Gizi Menurut TB/U Kelompok Pemberdayaan

\begin{tabular}{ccccc}
\hline Status Gizi (TB/U) & \multicolumn{2}{c}{ Sebelum Intervensi } & \multicolumn{2}{c}{ Setelah Intervensi } \\
& $\mathrm{N}$ & $\%$ & $\mathrm{n}$ & $\%$ \\
\hline Sangat Pendek & 11 & 18,3 & 8 & 13,3 \\
Pendek & 49 & 81,7 & 24 & 40,0 \\
Normal & 0 & 0 & 28 & 46,7 \\
\hline Jumlah & 60 & 100 & 60 & 100 \\
\hline
\end{tabular}

Berdasarkan tabel 9 dapat dilihat bahwa status gizi menurut TB/U mengalami perubahan setelah dilakukan intervensi. Tabel ini menggambarkan bahwa terjadi pergeseran status gizi berdasarkan Zscore TB/U di mana setelah diintervensi terjadi pergeseran dari sangat pendek meningkat menjadi pendek sebanyak 3 anak dan dari pendek meningkat menjadi normal sebanyak 28 anak.

\section{Analisis Bivariat Asupan Protein, Kalsium, Zink dan Z-Score TB/U antara Kelompok Perlakuan dan Kelompok Non pemberdayaan}

Tabel. 10

Perbedaan Nilai Rata-Rata Asupan Protein, Kalsium, dan Zink antara Kelompok Pemberdayaan dan Non Pemberdayaan

\begin{tabular}{lccc}
\hline Variabel & Pemberdayaan & Non pemberdayaan & p value \\
\hline Protein $(\mathrm{gr})$ & 27,54 & 28,83 & 0,113 \\
Kalsium $(\mathrm{mg})$ & 293,11 & 291,93 & 0,948 \\
Zink $(\mathrm{mg})$ & 5,16 & 3,96 & 0,0001 \\
\hline
\end{tabular}


Berdasarkan tabel 10 dapat diketahui bahwa nilai rata-rata asupan protein, kalsium, zink dan Z-Score TB/U pada kelompok pemberdayaan tidak jauh berbeda dengan kelompok non pemberdayaan. Setelah dilakukan uji $t$ independent dapat disimpulkan bahwa tidak ada perbedaan yang bermakna nilai rata-rata asupan protein dan kalsium antara kelompok perlakuan dengan kelompok non pemberdayaan (nilai $\mathrm{p}$ value $>\alpha$ ), hanya asupan zink yang memiliki perbedaan (nilai $p$ value $<\alpha$ ).

Artinya bahwa jika kelompok pemberdayaan diberikan intervensi pemberdayaan untuk meningkatkan konsumsi ikan maka asupan protein, kalsium dapat setara bahkan melebihi (khusus asupan zink) dengan anak seumur yang tidak mengalami stunting. sehingga pertambahan tinggi badan anak stunting dapat menyamai pertumbuhan tinggi badan anak yang tidak stunting, sehingga intervensi pemberdayaan pada ibu untuk meningkatkan konsumsi ikan pada penelitian ini dapat mengejar ketertinggalan pertumbuhan tinggi badan di masa lalu dan dapat dikejar pertumbuhan tinggi badan yang optimal jika konsumsi ikan dipertahankan seterusnya.

\section{PEMBAHASAN}

\section{Karakteristik Anak Usia 13-36 bulan}

Pada kelompok pemberdayaan di kedua desa memiliki kesamaan karakteristik jenis kelamin yaitu sama-sama sebesar 50\% untuk jenis kelamin laki-laki dan perempuan.

Dari kedua desa kelompok pemberdayaan diketahui umur anak yang lebih besar prevalensi mengalami stunting di umur 25-36 bulan yaitu sebesar 53,3\%. Hal ini terjadi karena di umur tersebut selain aktifitas anak yang meningkat, anak juga sebagian besar telah mengenal makanan jajanan. Makanan jajanan memang sangat mempengaruhi daya terima anak terhadap makanan yang disajikan di rumah, karena makanan jajanan lebih menarik dari segi warna, rasa dan variasinya. Oleh karena itu ketika peneliti memperkenalkan ikan untuk dikonsumi maka pengolahannya dalam bentuk nugget atau bola/bakso ikan karena makanan ini sudah menjadi trend makanan jajanan anak-anak.

\section{Karakteristik Orangtua Anak Usia 13-36 bulan}

Pada tabel 7 dan 8 dapat diketahui bahwa sebagian besar ibu dan ayah dari kelompok pemberdayaan untuk kedua desa tersebut berada pada rentang umur 20-40 tahun, artinya dari segi umur mereka termasuk dalam kelompok umur produktif.

Begitu juga dengan tingkat pendidikan orangtua dari kelompok pemberdayaan sebagian besar berada pada pendidikan SD, SMP dan SMA, hal ini menandakan bahwa rata-rata tingkat pendidikan orangtua hanya sampai ke pendidikan menengah saja. Tingkat pendidikan memiliki kontribusi terhadap kemampuan untuk memperoleh pengetahuan dengan baik. Ibu dengan tingkat pendidikan menengah diharapkan lebih memiliki sikap positif terhadap gizi makanan sehingga dapat membantu pemenuhan kebutuhan gizi yang cukup untuk keluarga.

\section{Perbedaan Asupan Protein, Kalsium dan Zink Sebelum dan Sesudah Intervensi Asupan Protein}

Data hasil penelitian menunjukkan nilai $\mathrm{p}<\alpha$ sehingga dapat disimpulkan bahwa ada perbedaan nilai rata-rata asupan protein sebelum dan sesudah intervensi pemberian nugget ikan lemuru, dengan selisih rata-rata kenaikan jumlah asupan protein sebesar $6,54 \mathrm{gr} / \mathrm{hr}$, dengan kenaikan asupan protein tersebut telah memenuhi $>80 \%$ angka kecukupan gizi anak usia 13-36 bulan. Pada kelompok non pemberdayaan juga ada 
perbedaan antara asupan protein sebelum dan sesudah, namun jika dilihat nilai rata-rata asupan protein lebih sedikit dibandingkan pada kelompok perlakuan, tetapi karena kelompok perlakuan adalah kelompok anak yang tidak mengalami stunting, tetap asupan protein mereka walau tidak dilakukan intervensi memiliki rata-rata asupan protein yang lebih tinggi dari kelompok pemberdayaan. Penelitian ini sejalan dengan penelitian Juhartini (2016) yang juga menunjukkan hasil ada perbedaan tingkat konsumsi protein sebelum dan sesudah pemberian PMT BMC kelor.

Asupan protein yang cukup akan menyediakan asam amino yang diperlukan tubuh untuk membangun matriks tulang dan mempengaruhi pertumbuhan tulang karena protein berfungsi untuk memodifikasi sekresi dan aksi osteotropic hormone IGF-1, sehingga asupan protein dapat memodulasi potensi genetik dari pencapaian peak bone mass. Pemberian asupan zat gizi yang adekuat berpengaruh pada pola pertumbuhan normal sehingga dapat terkejar (catch up). Prevalensi stunting pada kelompok anak dengan asupan protein rendah lebih besar 1,87 kali daripada kelompok anak dengan asupan protein cukup (Sari et al., 2016).

\section{Asupan Kalsium}

Asupan kalsium pada kelompok pemberdayaan sebelum diintervensi dengan nilai rata-rata $197,3 \mathrm{mg} / \mathrm{hr}$, sesudah dilakukan intervensi pemberdayaan ibu dan pendampingan pemberian nugget ikan lemuru menjadi asupan rata-rata kalsium sebesar $293,11 \mathrm{mg} / \mathrm{hr}$, dengan selisih kenaikan asupan rata-rata sebesar 95,8 mg/hr. Hasil uji statistik memberikan hasil nilai $\mathrm{p}<\alpha$ sehingga dapat disimpulkan ada perbedaan nilai rata-rata asupan kalsium sebelum dan sesudah intervensi pada kelompok pemberdayaan, sedangkan jika dibandingkan dengan kelompok non pemberdayaan, maka asupan kalsium anak usia 13-36 bulan tanpa diintervensi sudah menyamai asupan pada kelompok pemberdayaan yang menandakan bahwa selama ini memang asupan kalsium kelompok non pemberdayaan lebih baik dari kelompok pemberdayaan. Intervensi yang dilakukan pada kelompok pemberdayaan menjadi satu faktor penyebab kenaikan sebesar 95,8 mg/hr asupan kalsium anak usia 13-36 bulan yang mengalami stunting.

Padahal asupan zat gizi mikro dalam hal ini kalsium sangat mempengaruhi pertumbuhan tulang anak. Rendahnya asupan kalsium dapat menyebabkan rendahnya mineralisasi matriks deposit tulang yang baru yang mempengaruhi kerja osteoblast, bila anak mengalami kekurangan tingkat berat dapat menyebabkan stunting. Asupan kalsium yang rendah dapat menyebabkan prevalensi stunting sebesar 3,625 kali jika dibandingkan dengan kelompok dengan asupan kalsium yang cukup (Sari et al., 2016)

Sejalan dengan penelitian yang dilakukan oleh Estillyta et al., (2018) ditemukan asupan kalsium yang rendah pada anak stunting dengan rerata sebesar 303,3 mg/hr. Menganalisis masih rendahnya asupan kalsium ini, maka sangat perlu dilakukan edukasi gizi ke ibu yang menyediakan makanan keluarga untuk dapat melakukan pemilihan bahan makanan yang mengandung kalsium yang tinggi, tidak mesti bersumber dari susu tetapi dapat diperoleh dari ikan dan sayuran hijau, sehingga asupan kalsium anak dapat memenuhi angka kecukupan gizi yang dianjurkan.

\section{Asupan Zink/Seng}

Asupan rata-rata zink pada kelompok pemberdayaan sebelum intervensi yang paling rendah sebesar $3,69 \mathrm{mg} / \mathrm{hr}$. Setelah dilakukan intervensi terjadi peningkatan asupan zink menjadi $5,16 \mathrm{mg} / \mathrm{hr}$, peningkatan asupan ini telah memenuhi AKG sebesar $>100 \%$ kebutuhan. Hasil uji statistik pada kelompok pemberdayaan memberikan nilai 
$\mathrm{p}<\alpha$, sehingga dapat disimpulkan bahwa ada perbedaan yang bermakna nilai rata-rata asupan zink sebelum dan sesudah pemberian intervensi.

Asupan zink untuk kelompok non pemberdayaan tidak jauh berbeda dibandingkan dengan kelompok pemberdayaan, yang berarti bahwa anak yang stunting dan tidak stunting memiliki asupan zink yang rendah. Dalam penelitian ini, temuan asupan zink pada anak yang tidak stunting juga perlu dicermati karena tidak menutup kemungkinan jika anak yang tidak stunting pada suatu hari kelak menjadi anak stunting.

Hal ini sejalan dengan penelitian Oktiva, Adriani (2017) yang menemukan rendahnya asupan zink pada anak stunting, dimana tingkat asupan zink yang kurang dari angka kecukupan gizi sebesar 72,22\%. Demikian juga dengan penelitian Sulistianingtias , Laila (2017) dimana sebesar 64,3\% dengan asupan zink yang kurang pada remaja mengalami stunting. Oleh karena itu perlu dilakukan upaya pemberian makanan yang mengandung zink yang dapat memenuhi kecukupan gizi anak. Dalam nugget ikan lemuru ini dalam satu kali pemberian telah menyumbang zink sebesar $1,57 \mathrm{mg}$, dan diperlukan dukungan dari makanan utama sehari-hari yang dapat memenuhi kebutuhan tersebut.

Rendahnya asupan zink dapat menimbulkan kadar zink dalam tubuh menjadi rendah dan berdampak pada kejadian stunting karena zink berperan dalam pertumbuhan linear anak. Namun, asupan zink dipengaruhi oleh jumlah dan bentuk zat zink yang dikonsumsi, diet yang meningkatkan absorpsi (protein). Zink juga berhubungan dengan hormon-hormon penting yang terlibat dalam pertumbuhan tulang seperti samatomedinc, osteocalcin, testosteron, hormon tiroid dan insulin.

\section{Perbedaan Z-Score TB/U Sebelum dan Sesudah Intervensi}

Penelitian ini memberikan hasil bahwa sebelum diberikan intervensi diketahui nilai rata-rata $Z$-Score $\mathrm{TB} / \mathrm{U}$ sebesar $-2,46$. Setelah dilakukan pemberian intervensi maka diperoleh hasil nilai rata-rata Z-Score TB/U sebesar -2,25. Setelah dilakukan uji statistik diperoleh nilai $\mathrm{p}<\alpha$ sehingga dapat disimpulkan bahwa ada perbedaan nilai ratarata $\mathrm{Z}$-Score $\mathrm{TB} / \mathrm{U}$ sebelum dan sesudah intervensi.

Penelitian ini juga sejalan dengan penelitian Juhartini (2016) tentang pemberian makanan tambahan biscuit dan bahan makanan campuran kelor terhadap BB dan TB balita gizi kurang di Wilayah Kerja Puskesmas Kalumpang Kota Ternate tahun 2015 selama 30 hari dengan hasil yang bermakna dimana balita mengalami kenaikan rata-rata TB sebesar 1,04 cm, kenaikan TB $0-0,5 \mathrm{~cm}$ pada 9 orang balita dan kenaikan TB > 1 $\mathrm{cm}$ pada 2 orang balita. Demikian juga dengan dengan penelitian Syarfaini et al., (2016) dimana anak sekolah dasar mengalami rata-rata kenaikan TB sebesar 0,54 cm ketika diberikan nugget tempe dengan substitusi ikan gabus selama 1 bulan.

Dari beberapa penelitian yang tersebut di atas, membuktikan bahwa pemberian makanan tambahan akan menaikkan TB anak yang mengalami stunting, percepatan pertambahan TB dalam penelitian ini dimungkinkan karena PMT yang diberikan berbahan ikan yang mengandung protein, kalsium dan zink yang tinggi. Namun penelitian ini bersifat pre-post test, sehingga kenaikan TB yang dicapai kemungkinan tidak hanya disebabkan oleh pemberian makanan tambahan saja tetapi juga oleh faktor lain seperti konsumi makanan utama anak. 


\section{Perbedaan Nilai Rata-Rata Asupan Protein, Kalsium, Zink dan Z-Score TB/U antara Kelompok Pemberdayaan dan Non Pemberdayaan}

Pada tabel 10 telah dapat dilihat bahwa setelah dilakukan uji statistik $t$ independent dapat diketahui bahwa tidak ada perbedaan yang bermakna antara asupan protein, kalsium dan Z-Score TB/U kelompok pemberdayaan dan non pemberdayaan $(p>\alpha)$, hanya untuk asupan zink terjadi perbedaan yang bermakna antara kelompok pemberdayaan dan non pemberdayaan $(\mathrm{p}<\alpha)$.

Keadaan ini menunjukkan bahwa pemberian intervensi untuk memberdayakan ibu atau meningkatkan kemampuan ibu dalam pengetahuan dan pengolahan ikan akan meningkatkan asupan protein, kalsium, dan zink. Peningkatan asupan gizi ini juga meningkatkan pertumbuhan TB anak stunting. Hal ini tergambar dari tabel 15 dimana setelah dilakukan intervensi nilai rata-rata asupan gizi tidak jauh berbeda dengan kelompok non pemberdayaan, untuk asupan kalsium dan zink bahkan melebihi asupan dari kelompok non pemberdayaan. Asupan yang hampir memenuhi ini juga memberikan pertambahan TB yang semirip dengan TB non pemberdayaan.

Sejalan dengan penelitian Mazengia, Biks (2018) yang mengemukakan bahwa pendidikan ibu menjadi faktor resiko penting untuk kejadian stunting di Indonesia, Cina Selatan dan Abeokuta, Southwest Nigeria. Ibu yang memiliki pendidikan dan pengetahuan yang baik akan memiliki kemampuan untuk menerima pengetahuan dan lebih terbuka terhadap informasi baru yang diberikan sehingga memiliki pemahaman yang lebih baik tentang gizi dan kesehatan. Pengetahuan menjadi salah satu faktor yang dapat meningkatkan otoritas yang lebih besar di rumah dan dapat meningkatkan produktivitas untuk memperbaiki dan meningkatkan status gizi keluarga dan anak. Oleh karena itu, peningkatan pengetahuan akan meningkatkan kemampuan perempuan dalam pemberian makanan keluarga, hal ini menjadi salah satu metode untuk mengurangi angka stunting.

Penelitian ini sejalan juga dengan penelitian Alaofe et al., (2017) yang melakukan penelitian tentang pemberdayaan ibu di distrik Kalaly, Benin Utara, dimana hasil penelitian memberikan asosiasi positif dari pemberdayaan perempuan (ibu) dengan keragaman diet, dimana ibu dapat bekerja secara sinergis dengan pendekatan berbasis makanan untuk meningkatkan kualitas makanan, sehingga perlunya memperkuat peran dan kepercayaan diri ibu dalam keluarga mereka.

\section{SIMPULAN}

Ada perbedaan yang bermakna nilai rata-rata asupan protein sebelum dan sesudah pemberian intervensi pemberdayaan ibu untuk perbaikan pola konsumsi ikan pada anak usia 13-36 bulan. Ada perbedaan yang bermakna nilai rata-rata asupan kalsium sebelum dan sesudah pemberian intervensi pemberdayaan ibu untuk perbaikan pola konsumsi ikan pada anak usia 13-36 bulan.

Ada perbedaan yang bermakna nilai rata-rata asupan zink sebelum dan sesudah pemberian intervensi pemberdayaan ibu untuk perbaikan pola konsumsi ikan pada anak usia 13-36 bulan. Ada perbedaan yang bermakna nilai Z-score TB/U sebelum dan sesudah pemberian intervensi pemberdayaan ibu untuk perbaikan pola konsumsi ikan pada anak usia 13-36 bulan. 


\section{SARAN}

Agar ibu atau orang terdekat yang menyiapkan makanan anak untuk meneruskan pemberian makanan berbahan dasar ikan, atau makanan lain yang mengandung protein, kalsium dan zink sesuai dengan angka kebutuhan anak dapat dilanjutkan sehingga dapat dikejar pertumbuhan tinggi badan yang optimal dan tidak lagi mengalami stunting.

Perlu dilakukan kegiatan penyuluhan, pelatihan pengolahan variasi makanan berbahan ikan dan pendampingan kepada ibu atau orang terdekat yang menyiapkan makanan anak secara berkala, sehingga asupan anak tetap sesuai dengan kebutuhan.

Agar Petugas Puskesmas yang melakuan kegiatan pengukuran tinggi badan anak di Posyandu dapat menindaklanjuti data yang ada sampai diketahui status gizi anak yang di data, sehingga yang mengalami keterlambatan pertumbuhan dapat dilakukan edukasi gizi ke pihak keluarga anak tersebut.

Perlu dilakukan kerjasama antara pihak pendidikan (perguruan tinggi) dengan Kepala Dinas Kesehatan bahkan Kepala Daerah untuk melanjutkan program gemar makan ikan.

Penelitian ini dapat dilanjutkan dengan memperluas daerah penelitian dan jumlah sampel yang lebih besar dengan kelompok umur yang berisiko terhadap status stunting.

\section{DAFTAR PUSTAKA}

Alaofe, H., Zhu, M., Burney, J., Rosamond, N., \& Douglas, T. (2017). Association Between Women's Empowerment and Maternal and Child Nutrition in Kalal' e District of Northern Benin. Food and Nutrition Bulletin, 38(3), 302-318

Estillyta, C., Candra, A., \& Binar, P. (2018). Asupan Vitamin D, Kalsium dan Fosfor pada Anak Stunting dan Tidak Stunting Usia 12-24 Bulan di Kota Semarang. Journal of Nutrition College, 7(1)

Gultom, H. E. R., \& Nainggolan, E. (2019). Pengaruh Pemberian Protein dan Seng dari Cookies Kaxang Merah terhadap Z-Score TB/U dan Seng Rambut pada Anak Stunting Usia 13-36 Bulan di Wilayah Puskesmas Pantai Labu. Politeknik Kesehatan Medan

Juhartini, J. (2016). Pengaruh Pemberian Makanan Tambahan Biskuit dan Bahan Makanan Campuran Kelor terhadap Berat Badan dan Hemoglobin. Studi pada Balita dengan Status Gizi Kurus di Wilayah Kerja Puskesmas Kalumpang Kota Ternate Tahun 2015. Hospital Majapahit, 8(2)

Kartini, A., Suhartono, S., Subagio, H. W., Budiyono, B., \& Emman, I. M. (2016). Kejadian Stunting dan kematangan Usia Tulang pada Anak Usia Sekolah Dasar di Daerah Pertanian Kabupaten Brebes. Jurnal Kesehatan Masyarajat, 11(2), 96103. https://doi.org/http://dx.doi.org/10.15294/kemas.v11i1.3521

Kementerian Kesehatan, RI. (2019). Kebijakan dan Strategi Penanggulangan Stunting di Indonesia

Mazengia, A. L., \& Biks, G. A. (2018). Predictors of Stunting among School-Age Children in Northwestern Ethiopia. Journal of Nutrition and Metabolism, 10, 1-7. https://doi.org/10.1155/2018/7521751

Oktiva, B. R., \& Adriani, M. (2017). Perbedaan Kadar Zink Rambut pada Anak Stunting dan Non Stunting pada Usia 12-24 Bulan di Kelurahan Tambak Wedi Kenjeran, Surabaya. Amerta Nutr, 133-142

Padila, P., Amin, M., \& Rizki, R. (2018). Pengalaman Ibu dalam Merawat Bayi Preterm yang Pernah dirawat di Ruang Neonatus Intensive Care Unit Kota Bengkulu. Jurnal Keperawatan Silampari, 1(2), 1-16. https://doi.org/10.31539/jks.v1i2.82 
Padila, P., Andari, F. N., \& Andri, J. (2019). Hasil Skrining Perkembangan Anak Usia Toddler antara DDST dengan SDIDTK. Jurnal Keperawatan Silampari, 3(1), 244-256. https://doi.org/10.31539/jks.v3i1.809

Panzilion, P., Padila, P., Amin, M., \& Andri, J. (2020). Perkembangan Motorik Prasekolah antara Intervensi Brain Gym dengan Puzzle. Jurnal Keperawatan Silampari, 3(2), 510-519. https://doi.org/https://doi.org/10.31539/jks.v3i2.1120

Rachim, A. N. F., \& Pratiwi, R. (2017). Hubungan Konsumsi Ikan terhadap Kejadian Stunting pada Anak Usia 2-5 Tahun. Jurnal Kedokteran Diponegoro, 6(1), 36-45. http://ejournal-s1.undip.ac.id/index.php/medico

Rahmawati, D. P., \& Hidayati, L. (2017). Perbedaan Kecukupan Protein, Zinc, Kalsium, dan Vitamin D pada Remaja Putri Stunting dan Non - Stunting di SMP $N 1$ Nguter Kabupaten Sukoharjo Perbedaan Kecukupan Protein, Zinc, Kalsium, dan Vitamin D pada Remaja Putri Stunting dan Non - Stunting di. Universitas Muhammadiyah Surakarta

Sari, E. M., Juffrie, M., Nurani, N., \& Sitaresmi, M. N. (2016). Asupan Krotein, Kalsium dan Fosfor pada Anak Stunting dan Tidak Stunting Usia 24-59 Bulan. Jurnal Gizi Klinik Indonesia, 12(4), 152-159. https://jurnal.ugm.ac.id/jgki

Sulistianingtias, S., \& Laila, E. (2017). Hubungan antara Asupan Zink dengan Kejadian Stunting pada remaja di Sukoharjo Jawa Tengah. Universitas Muhammadiyah Surakarta

Syarfaini, M., Satrianegara, F., \& Astari, R. A. (2016). Pengaruh Pemberian Nugget Tempe dengan Substitusi Ikan Gabus terhadap Status Gizi Anak Sekolah Dasar di MIS DDI Ainus Syamsi Kel. Lette Kota Makassar 2014. Al-Sihah : Public Health Science Journal, 8(2)

WHO. (2017). Early Child Development. https://www.tandfonline.com/loi/gecd20?open=187\&year=2017\&repitition=0\#vol 187_2017

Widianto, B. (2018). Upaya Konvergensi Program / Kegiatan Pencegahan Anak Kerdil (Stunting) Indikator Status Gizi Anak (Stunting). November, 1-14 